International Research Journal of Management, IT \& Social Sciences
Available online at https://sloap.org/journals/index.php/irjmis/
Vol. 7 No. 3, May 2020, pages: 91-97
ISSN: 2395-7492
https://doi.org/10.21744/irjmis.v7n3.922

\title{
Community Participation in Blangsinga Tourism Village Development
}

\begin{tabular}{|c|c|}
\hline & Ni Ketut Ayu Martini \\
\hline Article history: & Abstract \\
\hline $\begin{array}{l}\text { Submitted: } 27 \text { March } 2020 \\
\text { Revised: } 09 \text { April } 2020 \\
\text { Accepted: } 18 \text { May } 2020\end{array}$ & $\begin{array}{l}\text { This study aims to determine the form of community participation and } \\
\text { strategies to increase community participation in Blangsinga Tourism Village. } \\
\text { The theory used in this study is Community Based Tourism (CBT). The type } \\
\text { of data used in this study is qualitative data which is data in the form of } \\
\text { information either in the form of direct interviews or documents related to } \\
\text { research. Data sources used are divided into two, namely primary data and } \\
\text { secondary data. Based on the results of the research conducted, it can be }\end{array}$ \\
\hline $\begin{array}{l}\text { Keywords: } \\
\text { community participation; } \\
\text { village tourism; } \\
\text { Community-Based Tourism } \\
(\text { CBT }) \text {; }\end{array}$ & $\begin{array}{l}\text { concluded that the development of Blangsinga Tourism Village is inseparable } \\
\text { from the participation of the community. The form of Blangsinga community } \\
\text { participation in the planning and implementation stages. Efforts to increase } \\
\text { community participation are carried out by the village government and third } \\
\text { parties by making policies that certainly have a positive impact on the } \\
\text { community and the development of Blangsinga Tourism Village. }\end{array}$ \\
\hline
\end{tabular}

development concept;

International research journal of management, IT and social sciences (C) 2020. This is an open access article under the CC BY-NC-ND license (https://creativecommons.org/licenses/by-nc-nd/4.0/).

\section{Corresponding author:}

Ni Ketut Ayu Martini,

Undiknas Graduate School

J1. Waturenggong No. 164 Denpasar, Indonesia.

Email address: ayumartini93@gmail.com

${ }^{a}$ Undiknas Graduate School, Denpasar, Indonesia 


\section{Introduction}

Indonesia is a vast territory supported by diverse natural resources that have the potential to be utilized. The diversity of natural resources can be a capital for tourism if properly utilized according to its potential. The tourism sector is one of the most effective instruments in efforts to encourage regional development, community empowerment, and poverty reduction efforts. It can be mentioned that way because the tourism sector is a sector that can be developed by regions with the potential of their respective regions such as the natural potential they possess, cultural diversity, and the order of life of their people. Nowadays more and more areas are used potential which can certainly be developed into an attractive tourist destination. Indonesian tourism is being intensively developed, Bali's Central Statistics Agency (BPS) also noted the number of tourist villages rose by $32 \%$ in 2018. The last calculation was in 2018, there were 162 tourist villages, which in 2014 were only 122 tourist villages. The role of tourism destinations becomes important, especially in packaging people's lives and local culture into a tourist attraction (Andini, 2013; Herdiansyah, 2013). Thus there will be a reciprocal relationship between culture and the participation of local communities. This reciprocal relationship must be mutually beneficial, meaning that tourism must be able to improve culture and vice versa can foster tourism progress so that it can prosper the community, open up employment opportunities, eradicate poverty, and level development. According to Law Number 10 of 2009 concerning Tourism, in Chapter III article 5 letter e, the Principle of the Implementation of Tourism is Empowering the local community. The law has mandated that the development of Indonesian tourism must be able to empower local communities. Refer Law No. 10 of 2009 concerning tourism, the Government of the Republic of Indonesia Regulation Number 50 of 2011 concerning the National Tourism Development Master Plan 2010-2025, article 29 of the sixth section on Community Empowerment through Tourism, namely developing the potential of local resources through tourism villages. With this government regulation, each region can explore the potential of tourism in the area to empower existing communities by involving the entire community. Community empowerment in destinations through tourism business activities is one of the development models that is gaining a lot of attention from various groups and will become an important agenda in tourism development going forward. Sunaryo (2013), suggested that the development of tourism-oriented to community empowerment is an issue of the current strategy of tourism development. In tourism science, this strategy is known as Community Based Tourism (CBT) or community-based tourism.

\section{Literature review}

\section{a) Definition of Tourism Village}

Tourism Village is a rural area that offers a whole atmosphere that reflects the authenticity of rural areas both from socio-economic life, social culture, customs, daily life, has a unique architectural building and spatial structure of the village, or unique and interesting economic activities and has the potential to the development of various components of tourism, such as attractions, accommodation, food-drinks, souvenirs, and other tourism needs (Mtapuri \& Giampiccoli, 2013; Pitana, 2011; Palimbunga, 2018; Lepp, 2007; Lepp, 2008).

\section{b) Development Concept}

Development is a strategy used to advance, improve and improve the tourism conditions of an object and tourist attraction so that it can be visited by tourists and can provide benefits to the people around the object and attraction as well as to the government (Jones \& Jew, 2007; Granger, 1988). The development of natural tourism objects is very closely related to the increase in productivity of natural resources in the context of economic development so that it is always faced with conditions of the interaction of various interests involving aspects of the forest area, regional government, community aspects, and the private sector in a regional spatial system (Hayati, 2010; Ziku, 2015; Moleong, 2014).

\section{c) Community Participation}

Participation is the involvement of a person or several people in an activity. Involvement can be in the form of mental and emotional as well as physical involvement in using all the capabilities it has in all activities carried out and supporting the achievement of objectives and responsibilities for all of its involvement (Tosun, 2006; Davidson et al., 2007; Tosun, 2000). Some factors that influence community participation are age, sex, education, occupation and income, length of stay. Here are the types of levels of participation according to Arnstein (1996):

1) Citizen Power (Citizen Control, Delegated Power, Partnership)

2) Tokenism (Placation, Consultation, Informing) 
3) Nonparticipation (Therapy, Manipulation)

\section{d) Community-Based Tourism (CBT)}

In the ASEAN Community Based Tourism Standard (2016), Community Based Tourism (CBT) is a tourism activity that is owned and run by the community and coordinated with the community and contributes to the welfare of the community by supporting the livelihoods of the community and protecting its traditions, culture and natural resources (Tolkach \& King, 2015; Ruiz-Ballesteros, 2011; Lee \& Jan, 2019; Wisudawati \& Maheswari, 2018). Community-based tourism focuses on the involvement of local communities which is an absolute requirement to achieve the development of tourist attractions in a destination (Purmada \& Hakim, 2016; Rizkianto \& Topowijono, 2018; Rochman, 2016). The basic principle of Community Based Tourism is to open space and opportunities for the community to actively participate in the development of a tourist attraction, by participating, the local community can benefit and benefit economically from their participation, besides, the local community is also responsible for maintaining and conserving tourism resources in the area where they live.

\section{Materials and Methods}

This type of research in this journal uses a qualitative descriptive method with a case study approach. Location in this study is Blangsinga Tourism Village, Blahbatuh District, Gianyar Regency, Bali Province, data collection techniques used are observation, interviews, and documentation, the research informants are Blangsinga Village community, Blangsinga Village Apparatus, and Gianyar Regency Tourism Office. In this study using technical triangulation because the source is the same but the technique is different, namely through interviews and rechecking through observation or documentation Data analysis techniques used in this study are qualitative analyzes used by researchers as suggested by Miles and Hubberman (Sugiyono, 2017) namely data collection, data reduction, data presentation, and the final step is concluding.

\section{Results and Discussions}

Blangsinga Tourism Village is started from the Google Maps application. Where was said by Mr. Wayan Alit Prista as the Head of the Banjar Blangsinga that many foreign tourists who wanted to go to the Tegenungan waterfall but were directed to search for the waterfall with google maps through Blangsinga village road? The stray tourist approached the village youths who happened to gather at the side of the village road. This often happens so that the young man there directs the tourists to the Songongan waterfall which is now better known as the Blangsinga waterfall. From this, in 2016 a group of waterfalls was formed to become a tourist attraction. The group or it could be said that the tour manager at that time asked for funds from the village head to build access to the waterfall. With these funds a ladder was built into the waterfall which at that time could be said to be far from feasible. The construction of stairway access to the waterfall was carried out by the community in cooperation (Telfer \& Sharpley, 2015; Sudana, 2013). When the access road is complete, the Blangsinga waterfall tourism object has been opened and tourist visits are only around 20-30 people per month. These problems make tourism managers take the initiative to hold partners in the development of this Blangsinga waterfall tourism object, the Gianyar Regency Tourism Office. However, because the village office did not approve it for reasons of sharing the results by the regional government and the village, the agreement was not continued. The village administration suggested that tourism management should cooperate with the village administration only with an agreement on the sharing of $60 \%$ of the village and $40 \%$ of the tour manager. In 2017 due to the busy schedule of the tour operators, the management of the Blangsinga waterfall tourism object was given entirely to the village apparatus. After walking, village officials learned that the owner of Krisna Holding, "Ajik" Krisna was born in Blangsinga Village. After learning this fact, the village administration faces Krisna Holding. The meeting produced results where Ajik Krisna agreed to the collaboration that was offered because he wanted to advance the waterfall tour into a tourist village area, due to his devotion to wanting to develop the economy in his native land. After learning this fact, the village administration faces Krisna Holding. The meeting produced results in which Ajik Krisna agreed to the collaboration that was offered because he wanted to advance the waterfall tour into a tourist village area, due to his devotion to wanting to develop the economy in his native land. After learning this fact, the village administration faces Krisna Holding. The meeting produced results where Ajik Krisna agreed to the collaboration that

Title Martini, N. K. A. (2020). Community participation in Blangsinga tourism village development. International Research Journal of Management, IT and Social Sciences, 7(3), 91-97. https://doi.org/10.21744/irjmis.v7n3.922 
was offered because he wanted to advance the waterfall tour into a tourist village area, due to his devotion to wanting to develop the economy in his native land.

After obtaining an agreement, Krisna began to assist with the initial steps of the physical arrangement of the Blangsinga Waterfall attraction, the development of Krisna By - By Blangsinga, Village Facing Arrangement, Village Entrance Development, and supporting facilities (D'Tukad restaurant, Mooi River Valley, and Duck Crisp) which can also be assisted by private partners from Krisna Holding. After physical arrangement, Krisna Holding helped in marketing Blangsinga Waterfall Tourism Object and Blangsinga Tourism Village to their company's partner network, as well as officially establishing Blangsinga Tourism Village in early 2018. In addition to marketing, steps in maintaining the quality of Tourism Village and Tourism Objects that are worthy of visiting tourists also assisted by Krisna Holding. The development of the Blangsinga Waterfall Tourism Object happened very drastically after the promotion conducted by Krisna Holding. Tourist visits can reach 100-200 tourists per day, or 10-15 Tourism Buses per day. This achievement also had a positive impact on the entire village because the Blangsinga Tourism Village was increasingly recognized as a Tourist Destination Area with its main tourist attraction being Blangsinga Waterfall.

In this discussion, several forms of local community participation from the beginning to the present will be explained along with the development of tourism in Blangsinga Tourism Village. The form of local community participation in Blangsinga Tourism Village from the beginning until now is, Community Participation can be found in the planning process (Ahsani et al., 2018; Yarisetouw, 2012). Planning is a process that involves efforts made to anticipate future trends and determine the right strategy to realize the organization's goals and objectives. Activities in planning include: (1) determining the target market, formulating strategies to reach the target market, determining the resources needed, and setting standards/indicators of success in achieving the goals and target market, and (2) involvement of local communities in identifying problems and development potential according to environmental conditions. One of the efforts of the village government or village apparatus to support the implementation of the formation of Blangsinga Tourism Village is by holding a meeting called "The Great Persamuan". Where this activity aims to socialize to the community to support the ideas or ideas of the village apparatus to make this village as a tourist village as well as invite the community to participate and work together to build this tourist village. At this planning stage, the community was given the opportunity to provide advice in the planning of this Blangsinga Tourism Village but the decision was in the village apparatus and a third party namely Krisna Holding. This shows that community participation in planning is at the therapeutic stage. At the stage of therapy there has been communication but is limited. The initiative comes from the government and is only one direction. Community participation is given the opportunity to opinion and is heard, but they cannot get a guarantee that their views will be considered by the decision holder. Participation at this level has very little possibility to produce a change in society. Second is Community Participation in implementation. Participation is a form of involvement of a person or group of people in doing something. The form of community participation in the development of Blangsinga Tourism Village can be seen from the community's involvement in various activities agreed upon by the community and the Village Apparatus and Krisna Holding in implementing tourism development in Blangsinga Tourism Village.

The concept of Community-Based Tourism (CBT) is applied by Blangsinga Tourism Village in making policies to increase community participation to optimize the development of Tourism Villages. There are several programs implemented, namely cooperation to maintain the cleanliness of Blangsinga Tourism Village so that it looks clean every day, this program is only implemented until the end of 2019 and in 2020 the Village Office has been able to pay cleaning staff to maintain the cleanliness of Blangsinga Tourism Village from sweeping, watering plants in the area of the road to attractions and care for the environment. Furthermore, the development of community soft skills is assisted by Krisna Holding. Krisna's party helped provide training in human resources. The training is in the form of tourism management, accommodation, language, and hygiene management training. This activity indirectly evokes a sense of responsibility of villagers in managing their village so that it can still become an increasingly attractive tourist village going forward. Krisna helps in exploring the potential of human resources that can be useful for tourism. One of the activities carried out is by involving the community directly at Krisna events.

\section{Conclusion}

Based on the results of research conducted it can be concluded that:

a) Blangsinga Tourism Village was formed from an association between certain parties, starting from the Community, Village Apparatus, and Third Party (Krisna Holding). Certain parties spread their ideas, find partners, and realize innovation, and this is Blangsinga Tourism Village. 
b) The collaboration carried out by Blangsinga Tourism Village with Krisna Holding is also the right choice and has a positive impact. These impacts include the ease of obtaining capital in developing activities to be carried out for rural tourism and planning for village development that is better planned and easy to realize because it is not blocked by funds.

c) Community participation in Blangsinga Tourism Village has been good, as evidenced from the beginning it has not been formed until now people always participate. The form of Blangsinga community participation is still in the planning and implementation stages while the supervision phase is only in the hands of the village government, third parties, and regional governments.

d) Efforts to increase community participation are carried out by village officials through policies according to the concept of Community-Based Tourism (CBT) which will certainly have a positive impact on the community and will further increase community participation to continue to participate in the development of Blangsinga Tourism Village.

\section{Recommendation}

To optimize the development of tourism villages, community participation is very important. Good cooperation between the community and the government is needed to always preserve the tourism village to be attractive to tourists. In addition to its natural beauty, tourist villages will be more attractive if there is support from the community.

Conflict of interest statement

The author declared that she has no competing interests.

Statement of authorship

The author has a responsibility for the conception and design of the study. The author has approved the final article.

Acknowledgments

I am grateful to two anonymous reviewers for their valuable comments on the earlier version of this paper.

Title Martini, N. K. A. (2020). Community participation in Blangsinga tourism village development. International Research Journal of Management, IT and Social Sciences, 7(3), 91-97. https://doi.org/10.21744/irjmis.v7n3.922 


\section{References}

Ahsani, R. D. P., Suyaningsih, O., Ma'rifah, N., \& Aerani, E. (2018). Penerapan konsep community based tourism (CBT) di desa wisata candirejo borobudur mewujudkan kemandirian desa. Publisia (Jurnal Ilmu Administrasi Publik), 3(2), 135. https://doi.org/10.26905/pjiap.v3i2.2270

Andini, N. (2013). Pengorganisasian komunitas dalam pengembangan agrowisata di desa wisata studi kasus: desa wisata Kembangarum, Kabupaten Sleman. Journal of Regional and City Planning, 24(3), 173-188. http://dx.doi.org/10.5614\%2Fjpwk.2013.24.3.2

Arnstein, S. R. (1969). A ladder of citizen participation. Journal of the American Institute of planners, 35(4), $216-224$. https://doi.org/10.1080/01944366908977225

Davidson, C. H., Johnson, C., Lizarralde, G., Dikmen, N., \& Sliwinski, A. (2007). Truths and myths about community participation in post-disaster housing projects. Habitat international, 31(1), 100-115. https://doi.org/10.1016/j.habitatint.2006.08.003

Granger, C. W. (1988). Some recent development in a concept of causality. Journal of econometrics, 39(1-2), 199211. https://doi.org/10.1016/0304-4076(88)90045-0

Hayati, S. (2010, July). Partisipasi masyarakat dalam pengembangan ekowisata di Pangandaran-Jawa Barat. In Forum Geografi (Vol. 24, No. 1, pp. 12-27). https://doi.org/10.23917/forgeo.v24i1.5012

Herdiansyah, H. (2013). Wawancara, observasi, dan focus groups sebagai instrumen penggalian data kualitatif. Jakarta: PT. Raja Grafindo Persada.

Jones, P. J., \& Jew, S. (2007). Functional food development: concept to reality. Trends in Food Science \& Technology, 18(7), 387-390. https://doi.org/10.1016/j.tifs.2007.03.008

Lee, T. H., \& Jan, F. H. (2019). Can community-based tourism contribute to sustainable development? Evidence from residents' perceptions of the sustainability. Tourism Management, 70, 368-380. https://doi.org/10.1016/j.tourman.2018.09.003

Lepp, A. (2007). Residents' attitudes towards tourism in Bigodi village, Uganda. Tourism management, 28(3), 876885. https://doi.org/10.1016/j.tourman.2006.03.004

Lepp, A. (2008). Tourism and dependency: An analysis of Bigodi village, Uganda. Tourism Management, 29(6), 12061214. https://doi.org/10.1016/j.tourman.2008.03.004

Moleong, L. J. (2014). Metode Penelitian Kualitatif (Edisi ke-33, cetakan ke-1). Bandung: PT Remaja Rosdakarya Offset.

Mtapuri, O., \& Giampiccoli, A. (2013). Interrogating the role of the state and nonstate actors in community-based tourism ventures: Toward a model for spreading the benefits to the wider community. South African Geographical Journal, 95(1), 1-15. https://doi.org/10.1080/03736245.2013.805078

Palimbunga, I. P. (2018). Keterlibatan Masyarakat Dalam Pengembangan Pariwisata Di Desa Wisata Tabalansu, Papua. Jurnal Master Pariwisata (JUMPA), 193-210. https://doi.org/10.24843/JUMPA.2018.v05.i01.p10

Pitana, I. (2011). Gde. Pemberdayaan \& Hiperdemokrasi dalam Pembangunan Pariwisata.

Purmada, D. K., \& Hakim, L. (2016). Pengelolaan Desa Wisata Dalam Perspektif Community Based Tourism (Studi Kasus pada Desa Wisata Gubugklakah, Kecamatan Poncokusumo, Kabupaten Malang). Jurnal Administrasi Bisnis, 32(2), 15-22.

Rizkianto, N., \& Topowijono, T. (2018). Penerapan Konsep Community Based Tourism dalam Pengelolaan Daya Tarik Wisata Berkelanjutan (Studi Pada Desa Wisata Bangun, Kecamatan Munjungan, Kabupaten Trenggalek). Jurnal Administrasi Bisnis, 58(1), 20-26.

Rochman, N. (2016). Model Pengembangan Desa Wisata Berbasis Pemberdayaan Masyarakat. Jurnal Equilibria Pendidikan, $1(1)$.

Ruiz-Ballesteros, E. (2011). Social-ecological resilience and community-based tourism: an approach from Agua Blanca, Ecuador. Tourism Management, 32(3), 655-666. https://doi.org/10.1016/j.tourman.2010.05.021

Sudana, I. P. (2013). Strategi Pengembangan Desa Wisata Ekologis di Desa Belimbing, Kecamatan Pupuan Kabupaten Tabanan. Analisis Pariwisata, 13(1), 11-31.

Sugiyono, P. D. (2017). Metode Penelitian Bisnis: Pendekatan Kuantitatif, Kualitatif, Kombinasi, dan R\&D.

Sunaryo, B. (2013). Kebijakan pembangunan destinasi pariwisata: konsep dan aplikasinya di Indonesia (No. 1). Penerbit Gava Media Kebijakan Pembangunan Destinasi Pariwisata: Konsep dan Aplikasinya di Indonesia.

Telfer, D. J., \& Sharpley, R. (2015). Tourism and development in the developing world. Routledge.

Tolkach, D., \& King, B. (2015). Strengthening community-based tourism in a new resource-based island nation: Why and how?. Tourism Management, 48, 386-398. https://doi.org/10.1016/j.tourman.2014.12.013 
Tosun, C. (2000). Limits to community participation in the tourism development process in developing countries. Tourism management, 21(6), 613-633. https://doi.org/10.1016/S0261-5177(00)00009-1

Tosun, C. (2006). Expected nature of community participation in tourism development. Tourism management, 27(3), 493-504. https://doi.org/10.1016/j.tourman.2004.12.004

Wisudawati, N. N. S., \& Maheswari, A. I. A. (2018). Potential of Silver Craft Product through to Community-Based for Tourism Sustainability in Celuk Village. International research journal of management, IT and social sciences, 5(1), 9-15.

Yarisetouw, B. (2012). Strategi Perencanaan Desa Tablanusu Distrik Depapre Sebagai Destinasi Pariwisata di Kabupaten Jayapura Provinsi Papua (Doctoral dissertation, Tesis). Denpasar: Universitas Udayana).

Ziku, R. M. (2015). Partisipasi masyarakat Desa Komodo dalam pengembangan ekowisata di Pulau Komodo. Jurnal Master Pariwisata (JUMPA). https://doi.org/10.24843/JUMPA.2015.v02.i01.p01

Title Martini, N. K. A. (2020). Community participation in Blangsinga tourism village development. International Research Journal of Management, IT and Social Sciences, 7(3), 91-97. https://doi.org/10.21744/irjmis.v7n3.922 